\title{
Physical and behavioural influences on larval fish retention: contrasting patterns in two Antarctic fishes
}

\author{
Emma F. Young ${ }^{1, *}$, Jennifer Rock ${ }^{2}$, Michael P. Meredith ${ }^{1}$, Mark Belchier ${ }^{1}$, \\ Eugene J. Murphy ${ }^{1}$, Gary R. Carvalho ${ }^{3}$ \\ ${ }^{1}$ British Antarctic Survey, High Cross, Madingley Road, Cambridge CB3 0ET, UK \\ ${ }^{2}$ Department of Zoology, University of Otago, Dunedin 9054, New Zealand \\ ${ }^{3}$ School of Biological Sciences, Bangor University, Bangor LL57 2UW, UK
}

\begin{abstract}
Waters around South Georgia are amongst the most productive in the Southern Ocean, and support internationally important fisheries. However, there is significant inter-annual variability in fish stocks, and some species have failed to recover from historical overfishing. Dispersal and retention of the planktonic eggs and larvae of marine fish can play a key role in the maintenance of adult stocks. We use a numerical modelling approach to examine the influence of oceanographic and life-history variability on the dispersal and retention of 2 Antarctic fishes: Champsocephalus gunnari (mackerel icefish) and Notothenia rossii (marbled rockcod). Mean retention of $N$. rossii larvae was predicted to be $5.3 \%$, considerably lower than that of C. gunnari $(31.3 \%)$, a difference related to the longer planktonic period of the former. Such apparent loss of larvae from local recruitment grounds may contribute to the failure of the N. rossii population to recover from its collapse in the 1970s. However, retention of both species showed high interannual variability. Dispersal and retention of C. gunnari were strongly influenced by location of the spawning site, with the greatest contribution to overall retention from spawning sites on the southwest South Georgia shelf. In addition, a consistent feature in C. gunnari was a lack of larval exchange between the proximate South Georgia and Shag Rocks shelves, regions separated by only $240 \mathrm{~km}$. Our findings provide insights into the demographic dynamics and connectivity of $C$. gunnari and $N$. rossii populations at South Georgia in relation to prospects for recovery and ongoing responses to environmental variability and change in the region.
\end{abstract}

KEY WORDS: Individual based model · Larval transport · Ocean circulation · Vertical migration · Fisheries management · Population connectivity

\section{INTRODUCTION}

The maintenance of adult fish populations is influenced by multiple factors, including the successful dispersal and retention of their planktonic eggs and larvae (Trippel \& Chambers 1997, Sponaugle et al. 2002, Lowe \& Allendorf 2010). Such processes represent a fundamental issue in 'supply-side ecology', which focuses on the influence of temporal and spatial variability of larval supply on adult population dynamics. Tracking actual dispersal in aquatic environments is a significant challenge due to the microscopic size of eggs and larvae, their highly dynamic and typically patchy distribution, and the lack of an appropriate tracking method. Indirect techniques using geochemical and genetic markers can provide insight on the spatial scales of population connectivity among multiple populations (Cowen \& Sponaugle 2009), though such techniques are limited in their temporal and spatial resolutions. A complementary 
approach is the utilization of high-resolution biophysical models that can resolve the effects of spatial and temporal environmental variability (including oceanographic flow fields) and life history on patterns of dispersal and retention. Individual based models (IBMs), which determine the Lagrangian pathways of planktonic stages of marine organisms, have become a central approach for such studies (Werner et al. 2001). These models include essential biological parameterisations specific to the modelled species, such as spawning locations and periods, planktonic duration and recruitment criteria, and advanced models can also incorporate feeding behaviour, growth and predation (Bartsch \& Coombs 2004, Daewel et al. 2008).

Here, we employ IBMs to examine the influences on dispersal and retention for 2 species of Antarctic fish with differing life-history characteristics, Champsocephalus gunnari and Notothenia rossii. We focus on the South Georgia region in the Southern Ocean where both species have historically been fished. South Georgia is a sub-Antarctic island located at the northern boundary of the Scotia Sea on the North Scotia Ridge (Fig. 1a). The island is separated from the surrounding deep ocean by a shelf of about 50 to $150 \mathrm{~km}$ width, with an average depth of about $200 \mathrm{~m}$. To the west of South Georgia, and separated by a deep channel of about $1500 \mathrm{~m}$ depth, is Shag Rocks, a further shallow plateau with several rocky outcrops. South Georgia and Shag Rocks lie in the path of the Antarctic Circumpolar Current (ACC), with the Polar Front (PF) lying to the north, and the Southern ACC Front (SACCF) looping anticyclonically around South Georgia from the south before retroflecting to the east (Orsi et al. 1995, Thorpe et al. 2002, Meredith et al. 2003b). Despite its location within the ACC, the shelf waters adjacent to South Georgia often show properties that are markedly different from the open ocean waters beyond, indicating that cross-shelf-break transport can be restricted (Brandon et al. 1999, 2000, Meredith et al. 2005). Notwithstanding this, crossshelf-break exchange of waters has been demonstrated using near-surface drifters and other techniques, with the dominant on-shelf flow of waters being predominantly from the south (Meredith et al. 2003a, 2005).

Although much of the Southern Ocean is characterised by high-nutrient low-chlorophyll conditions, the waters around South Georgia are biologically highly productive and support significant international fisheries. Historically, the peak in the fin-fish fisheries was in the $1970 \mathrm{~s}$, after which they suffered a rapid decline resulting in widespread closures (Myers \& Worm 2003, Agnew 2004, Kock

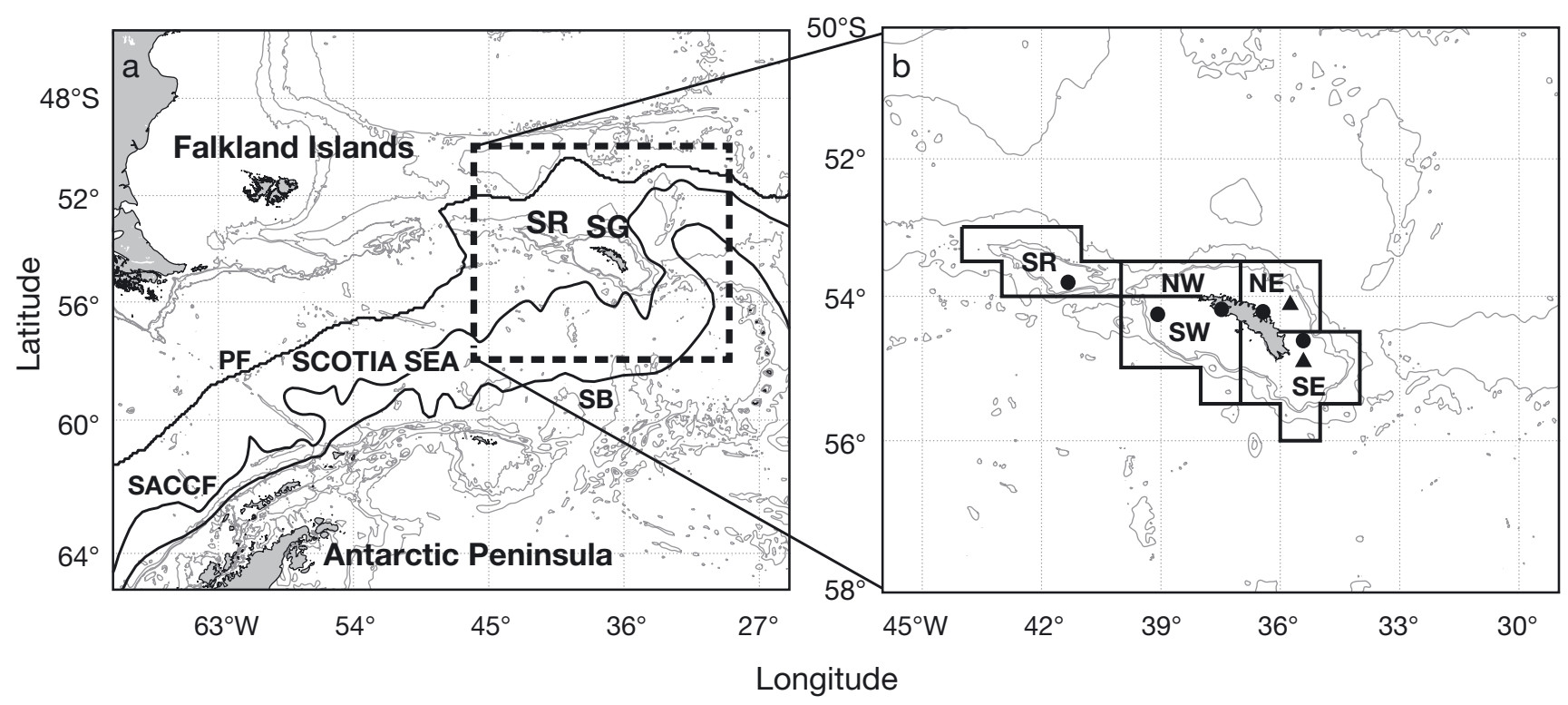

Fig. 1. (a) Location of South Georgia (SG) and Shag Rocks (SR). Dashed lines: model region. Solid black lines: mean positions of the Polar Front (PF) (following Moore et al. 1997), the Southern Antarctic Circumpolar Current Front (SACCF) and the southern boundary of the ACC (SB) (both from Thorpe 2001). (b) Model region. Black lines: specific shelf regions used in the retention analyses around South Georgia (NW, SW, SE, NE) and Shag Rocks (SR). Model spawning sites for Champsocephalus gunnari $(\bullet)$ and Notothenia rossii $(\mathbf{\Delta})$. Grey lines $=$ depth contours at 500, 1000, 2500 and $5000 \mathrm{~m}$ from Smith \& Sandwell (1997) 
et al. 2007). Although some fisheries have since reopened, albeit with lower catch limits, many remain closed due to failure of the stocks to recover. There is, moreover, significant inter-annual variability in fish stocks (Kock et al. 2007). Understanding the underlying influences on stock size, including the supply of larvae, is vital for effective management and conservation of fisheries resources. Here we concentrate on the dispersal and retention of Champsocephalus gunnari and Notothenia rossii eggs and larvae. Whilst $N$. rossii is no longer commercially fished due to historic depletion of the fish stocks and their failure to recover, $C$. gunnari is fished on both the South Georgia and Shag Rocks shelves, and there is controversy concerning the degree of connectivity between these 2 shelf populations. Analyses of biological characteristics (North 1996, 2005), parasite infestation (Sosinski \& Janusz 2000) and allozyme data (Carvalho \& Lloyd-Evans 1990) suggested a degree of geographic isolation despite their relative proximity. However, statistical analyses of morphometrics and meristics of fish from the 2 areas revealed no differences in support of geographic isolation (Kock 2005). In addition, genetic analyses using mtDNA and nuclear (single nucleotide polymorphism) markers found no significant differentiation between C. gunnari populations at Shag Rocks and South Georgia (Kuhn \& Gaffney 2006). In the present paper we describe the use of IBMs to investigate oceanographic, life history and behavioural influences on the dispersal and retention of the planktonic phases of $C$. gunnari and N. rossii. The results inform our understanding of the dynamics of the fish populations at South Georgia and Shag Rocks and have important implications for fisheries management in the region, especially in light of accelerating environmental change in Antarctic waters (e.g. Whitehouse et al. 2008).

\section{MATERIALS AND METHODS}

\section{Simulated fish species}

Mackerel icefish Champsocephalus gunnari is a widely distributed low-Antarctic species found around sub-Antarctic islands and at the northern end of the Antarctic Peninsula (Gon \& Heemstra 1990, Kock \& Everson 2003). They spawn benthic eggs (Everson et al. 2001) in deeper (>80 m) inshore waters and fjords (Kock \& Kellerman 1991). Thus, for the simulations of dispersal we excluded the egg phase. Data suggest that there are 2 spawning and hatching periods around South Georgia and Shag Rocks (North \& Murray 1992). The earlier hatching period (May to June) corresponds to Shag Rocks and to offshore shelf areas to the north of South Georgia, while hatching at nearshore South Georgia sites occurs between August and October. The larvae spend $\sim 3$ mo dispersing passively with the ocean currents (Duhamel 1995) before developing into juveniles and recruiting to a suitable inner shelf nursery ground. Although later-stage $C$. gunnari larvae are thought to undergo diel vertical migration, occupying the upper $20 \mathrm{~m}$ of the water column during the day and descending to depths of between 60 and $100 \mathrm{~m}$ at night (North \& Murray 1992), early-stage larvae are thought to be dispersed throughout the upper 100 $\mathrm{m}$ of the water column.

The marbled rockcod Notothenia rossii shares a similar distribution to mackerel icefish, but there are marked differences in their early life histories. $N$. rossii is believed to spawn in offshore shelf areas (Kock \& Kellermann 1991) with depths of around 120 to $350 \mathrm{~m}$ (Gon \& Heemstra 1990). Unlike Champsocephalus gunnari it spawns pelagic eggs between April and June around South Georgia (Gon \& Heemstra 1990, Kock \& Kellermann 1991). The eggs develop into larvae after $\sim 4$ mo (Kock \& Kellermann 1991), and then into blue fingerlings after about a further 2 mo. At this stage they migrate inshore to kelp beds (Gon \& Heemstra 1990). N. rossii eggs are found in the top $100 \mathrm{~m}$ of the water column, with their larvae in the upper $50 \mathrm{~m}$ (A. W. North pers. comm.). Although the vertical migratory behaviour of $N$. rossii larvae is unknown, observations of other fish species around South Georgia suggest that most undertake some form of diurnal vertical migration (North \& Murray 1992).

\section{Ocean circulation model}

Hourly flows for the South Georgia region were generated using a validated high resolution $(\sim 3 \mathrm{~km})$ hydrodynamic model (Young et al. 2011) for 1997 to 2000. This period includes $3 \mathrm{yr}$ with relative extremes in atmospheric forcing over the Southern Ocean, associated with extreme phases of largescale coupled modes of inter-annual climate variability (see Meredith et al. 2008 for full discussion). This choice of years enables robust inferences concerning larval dispersal and retention to be made, even accounting for possible extreme events in their 
physical forcing. The hydrodynamic model is an application of the Proudman Oceanographic Laboratory Coastal Ocean Modelling System (POLCOMS), a 3-dimensional finite difference primitive equation model (described by Proctor \& James 1996, Holt \& James 2001), with spherical polar $s$ coordinates (Song \& Haidvogel 1994), specifically the terrain-following $s$-coordinate transformation described in Holt \& James (2001). The model grid (Fig. 1b) extends from $58^{\circ} \mathrm{S}, 46^{\circ} \mathrm{W}$ to $50^{\circ} \mathrm{S}, 29^{\circ} \mathrm{W}$, with a horizontal grid spacing of $1 / 20^{\circ}$ longitude by $1 / 40^{\circ}$ latitude $(\sim 3 \mathrm{~km})$, and 45 layers in the vertical. Lateral open boundary forcing included tidal data from the Oregon State University global tidal model, TPXO6.2 (Egbert \& Erofeeva 2002), and baroclinic forcing derived from $5 \mathrm{~d}$ mean fields generated by the Ocean Circulation and Climate Advanced Modelling Project (OCCAM; Webb et al. 1998) $1 / 4^{\circ}$ model. Atmospheric variables from 6 hourly ECMWF ERA-40 reanalysis data (Uppala et al. 2005) provided the surface heat and momentum forcing, with surface freshwater fluxes calculated by combining daily precipitation rates from ECMWF ERA-40 and the evaporative loss term of the bulk heat flux formulae. Daily freshwater fluxes (predominantly glacial melt) at the South Georgia coast were estimated using a theoretical approach. The volume of freshwater discharge was estimated from the historical mean annual precipitation observed at South Georgia, assuming the system to be in steady state. Spatial variability in freshwater fluxes was incorporated by using satellite imagery to identify the main freshwater sources, with the relative magnitude of the sources determined from the relative sizes of their catchment areas. The seasonal cycle was calculated through a consideration of positive degree-days (PDD), with the assumption that volume of melt is proportional to the PDD cycle. Direct runoff was assumed to follow the same seasonal pattern as melt. Daily PDD was calculated as (Vaughan 2006):

$$
P D D=\sum_{i=0 h}^{i=18 h} T_{i}\left(t_{i+1}-t_{i}\right) \alpha\left(T_{i}\right)
$$

where $\alpha\left(T_{i}\right)=1$ if $T_{i}>0^{\circ} \mathrm{C}$ or $\alpha\left(T_{i}\right)=0$ if $T_{i} \leq 0^{\circ} \mathrm{C}$. Here, $T_{i}$ is the surface temperature in degrees Celsius, $t_{i}$ is the time expressed in fractions of a day and $\alpha$ is the binary function expressing whether or not melt will occur. Due to a lack of consistent recent temperature observations at South Georgia, historical data were used to calculate a mean seasonal PDD cycle. Full details of the hydrodynamic model may be found in Young et al. (2011).
Comparisons with observational data have shown the model to reproduce key features of the oceanography around South Georgia (Young et al. 2011). Predicted currents on and around the South Georgia shelf show a high degree of spatial and temporal variability on short (weeks) and longer (seasonal and inter-annual) timescales. Such heterogeneity stems from the combined interactions of the local bathymetry, variability in the atmospheric forcing (including direct wind forcing) and variability in the large-scale oceanography (in particular the strength and proximity to the South Georgia shelf of the SACCF). The model reproduces the seasonal cycle in stratification, with horizontal density gradients driving a temporally variable shelf-break front, in agreement with observations (Meredith et al. 2005). Near-surface off-shelf flows and strong vertical salinity gradients are predicted on the northern shelf during summer and autumn, when there are significant freshwater inputs from glacial melt. Variability in the large-scale oceanography is predicted by the model, in particular the high degree of temporal and spatial variability in the position of the SACCF (Meredith et al. 2003b). A strong and persistent full-depth northward flow between the South Georgia and Shag Rocks shelves is also predicted. This is confirmed by observed drifter tracks (Fig. 2). One drifter passed between the South

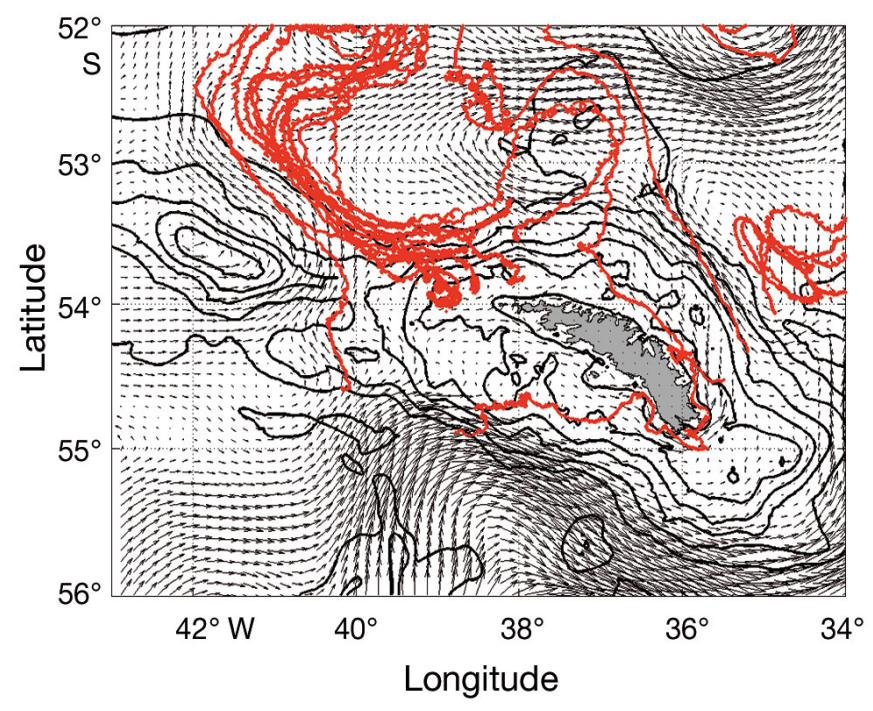

Fig. 2. Comparison of model-predicted mean near-surface flows $\left(\mathrm{m} \mathrm{s}^{-1}\right)$ for autumn 2000 (longest arrow represents $0.5 \mathrm{~m} \mathrm{~s}^{-1}$, every third grid cell shown) with observed drifter tracks (solid red lines) from passive drifters, drogued at 20 and $50 \mathrm{~m}$ and deployed January to February 2002 during RRS 'James Clark Ross' Cruise JR70 (Meredith et al. 2003a). Solid black lines: model depth contours at 100, 200, 500, $1000,2000,3000,4000$ and $5000 \mathrm{~m}$ 
Georgia and Shag Rocks shelves, as could be inferred from the predicted currents. The accuracy of model predictions is limited by uncertainties in the open boundary forcing and lack of inter-annual variability in freshwater fluxes (Young et al. 2011). In addition, the model resolution of $\sim 3 \mathrm{~km}$ is not sufficient to resolve very fine-scale flows within coastal bays and fjords, the implications of which are discussed later. However, these comparisons demonstrate the ability of the numerical model to reproduce key features observed in the oceanography around South Georgia.

An underlying feature associated with the South Georgia shelf is a tendency for anticlockwise flows around the island on the southern shelf east of $\sim 38.5^{\circ} \mathrm{W}$, continuing on the northern shelf, with offshelf flows to the north and northwest of the island. The preferred export pathway from the northwest South Georgia shelf to the west and then north of Shag Rocks is also evident in drifter tracks (Fig. 2). Flows from the southwest shelf tend to be northward, joining the aforementioned off-shelf flows to the north and northwest. To the west of South Georgia, flows tend to be weaker and more variable, and there is a persistent anticlockwise gyre. However, overlying these broad patterns, interannual variability also occurs in the shelf flows. Considering the predicted mean residual flows for austral spring in 1998, the dominant path of the SACCF impacted the South Georgia shelf at a more westerly point than in 1997 and 2000. This more westerly position of the front generated an increased northward flow along the shelf to the west of South Georgia, leading to a more easterly occurrence of offshore flows on the northern shelf. An increased anticlockwise coastal current around the southeast of the island was predicted for 1998 and 2000, likely due to stronger eastward winds in the atmospheric forcing data of the hydrodynamic model in these years (mean speeds of 4.81, 6.48 and $5.42 \mathrm{~m} \mathrm{~s}^{-1}$ in 1997, 1998 and 2000, respectively). The mean residual flows for austral winter in 2000 showed an anticlockwise shelf current circumnavigating the island. This was also weakly evident in 1997, but was not predicted in 1998. By contrast, there is little inter-annual variability in simulated flows at Shag Rocks: mean residual flows show a consistent anticlockwise shelf-edge current with little variability on the shelf. Such patterns are likely due to the lack of a significant land mass on the Shag Rocks shelf with relatively smooth bathymetry and no large-scale frontal features impacting the shelf.

\section{Individual based models}

Simulated hourly flows from the circulation model were used to advect Lagrangian particles representing the early life stages of Champsocephalus gunnari and Notothenia rossii. The model is based on the particle-tracking scheme described by Young (1996) and previously applied to studies of zooplankton on the South Georgia shelf (Ward et al. 2007), plaice eggs and larvae (Fox et al. 2006) and haddock larvae (Dickey-Collas et al. 2003). In summary, particles were advected at each model time step $(\Delta t ; 5 \mathrm{~min}$ ) according to the imposed horizontal velocity field (bilinearly interpolated to the particle positions) and using a second-order Runge-Kutta method. There was additional random horizontal and vertical diffusion ( $d_{h}$ and $d_{V}$, respectively), simulated using a random-walk approach of the form (Dyke 2001):

$$
\begin{aligned}
& d_{h}=R_{1} \sqrt{12 D_{h} \Delta t}, \text { in the direction } \theta=2 \pi R_{2} \\
& d_{V}=\left(2 R_{3}-1\right) \sqrt{6 D_{V} \Delta t}
\end{aligned}
$$

where $D_{\mathrm{h}}$ and $D_{\mathrm{v}}$ are the horizontal and vertical diffusion coefficients and $R_{1,2,3}$ are random numbers between 0 and 1 . Isotropic diffusion is assumed, with $D_{\mathrm{h}}=10 \mathrm{~m}^{2} \mathrm{~s}^{-1}$ and $D_{\mathrm{v}}=0.0001 \mathrm{~m}^{2} \mathrm{~s}^{-1}$. Model spawning sites (Fig. 1b) were located at observed spawning grounds derived from published literature (Everson et al. 2001, Frolkina 2002, Kock et al. 2004). Each of these spawning sites was represented as an ellipse (major and minor axes $\sim 5 \mathrm{~km}$ ), and model 'eggs' were released in a random distribution within this ellipse. A total of 500 eggs were released at each site, at daily intervals, with species-specific characteristics assigned to each egg and subsequent model 'larva'. Thus, for C. gunnari, larvae were released at hatching from each spawning site, distributed over the observed hatching periods (either 15 May to 30 June for sites CG1 and CG5, or 15 August to 15 October for sites CG2 to CG4), and dispersal was simulated for an assumed planktonic phase of 3 mo. By contrast, N. rossii eggs were released over the observed spawning period (15 April to 15 June), with dispersal of eggs and larvae simulated for assumed planktonic phases of 4 and 2 mo, respectively.

Over a 4 wk period encompassing the end of the planktonic phase, successful retention of individual larvae was assessed using species-specific retention criteria based on the known behaviour of young post-larvae of the 2 species. Thus, successful Champsocephalus gunnari retention was assumed if 
a larva was in an area with a depth of $<200 \mathrm{~m}$ at any point during the $4 \mathrm{wk}$ period, whilst successful Notothenia rossii retention required a larva to be within a coastal retention zone at any point during the $4 \mathrm{wk}$ period. A retention zone of 5 grid cells $(\sim 15$ $\mathrm{km}$ from the coast) was chosen based on the consideration of numerically generated flows at land boundaries in hydrodynamic models, which dissipate within about this distance. The simulated retention discussed in the present paper is not equivalent to recruitment to fish stocks because the model takes no account of egg, larval, or post-larval mortality, or of variability in the spawning stock biomass. Rather it represents the potential for larval supply to suitable recruitment grounds and its variability due to underlying physical and behavioural effects. Such collective proxies do, however, provide a reference baseline for comparative purposes across species, as well as relating potential to observed levels of population connectivity and the testing of potential underlying drivers of recruitment variability. The percentage of larvae successfully retained from each spawning site was calculated for each of the 3 study years (1997, 1998 and 2000) to assess the effect of inter-annual variability in the underlying flow fields. To enable a quantitative assessment of the geographical trends in retention, the South Georgia and Shag Rocks shelves were subdivided into the 5 regions illustrated in Fig. $1 \mathrm{~b}$, with 4 for South Georgia (NW, SW, SE and NE) and 1 encompassing Shag Rocks (SR).

Initial simulations were conducted assuming no vertical migration, with model eggs and larvae allowed to move randomly between the observed depth ranges described earlier. For comparison, a further series of simulations considered the effect of vertical migration of larvae on simulated dispersal and retention. Specifically, for Champsocephalus gunnari, a migratory behaviour approximating that observed for late-stage larvae (North \& Murray 1992) was imposed throughout the larval period, rising to the near-surface during the day, and sinking to no deeper than $100 \mathrm{~m}$ at night. Such behaviour was achieved in the model by assigning positive or negative buoyancy to the larvae during the day or night, respectively, with buoyancy speeds of $0.005 \mathrm{~m} \mathrm{~s}^{-1}$ imposed. The sign of the buoyancy was reversed at sunrise and sunset, with day length following a seasonal pattern calculated for the South Georgia location. A schematic illustrating the resultant vertical migration pattern at equinox is shown in Fig. 3a. Transit time at sunset and sunrise ( $d t_{i}$ Fig. 3a) was $\sim 5 \mathrm{~h}$ for those larvae in water deeper than $100 \mathrm{~m}$, reducing proportionately for water depths (and thus maximum larval depths) shallower than this. By contrast, a nocturnal migration pattern was assumed for Notothenia rossii larvae, as this is the pattern most often displayed by marine species studied to date (Forward 1988), with larvae rising to the near-surface at night and moving deeper in the water column during the day (to a maximum depth of $50 \mathrm{~m}$; A. W. North pers. comm.).

Finally, the effect of the timing of spawning on successful retention and geographical distribution was assessed by dividing each spawning period into thirds: early, middle and late spawning.
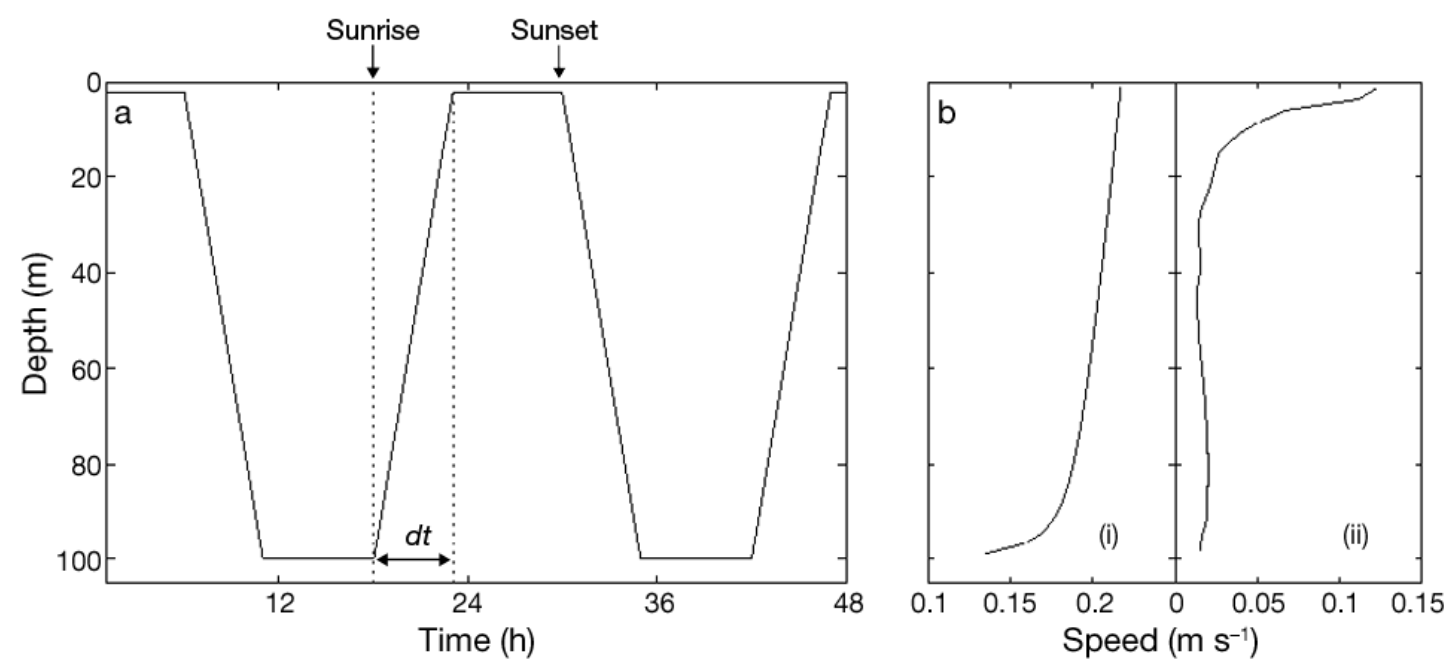

Fig. 3. (a) Vertical migration scheme for Champsocephalus gunnari larvae at equinox, for local water depths $>100 \mathrm{~m}$. Transit time, $d t$, is shown by the dotted lines. (b) Example vertical current profiles for locations on the NE shelf (i) and at the mouth of Cumberland Bay (ii) 

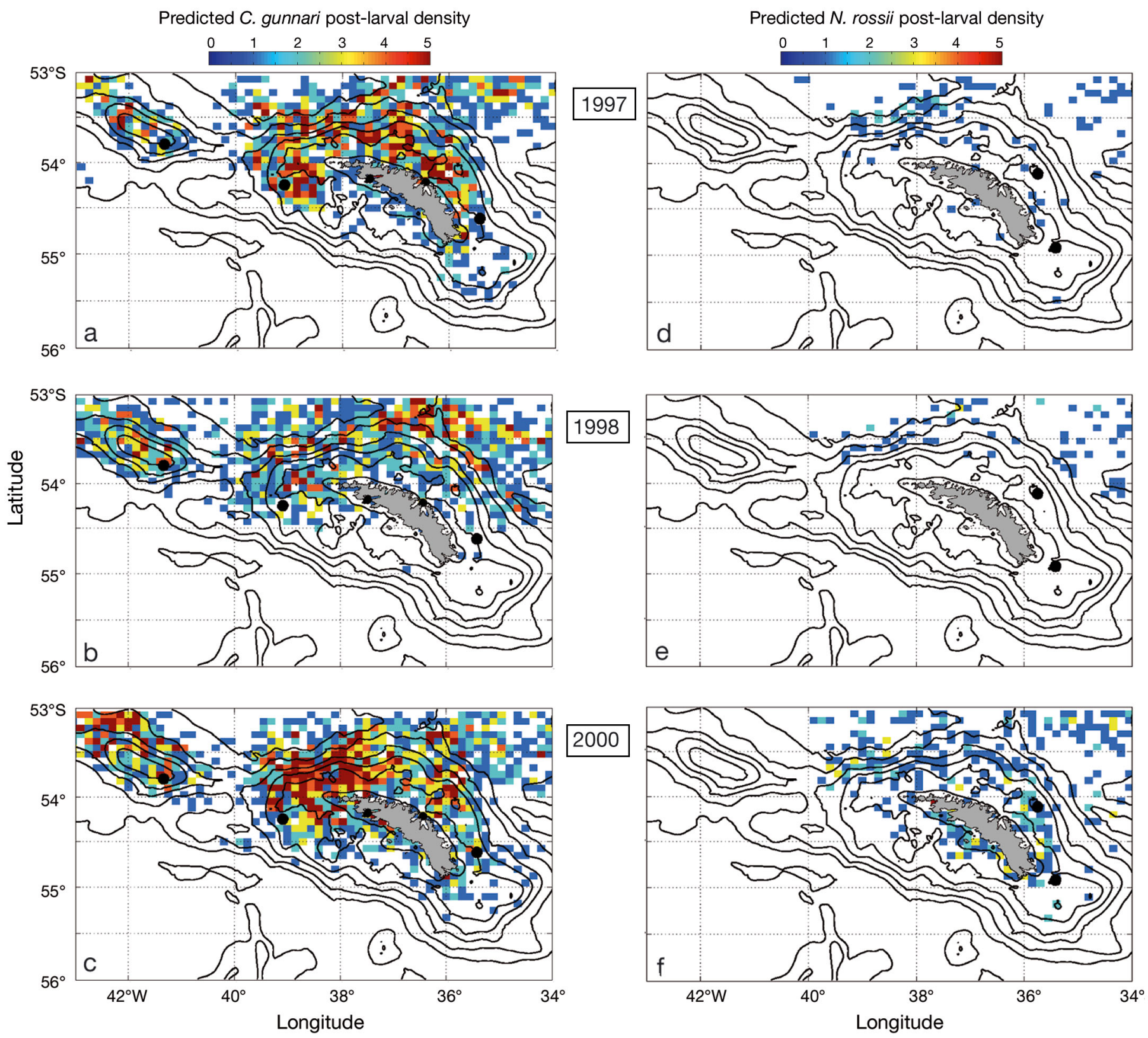

Fig. 4. Champsocephalus gunnari (a,b,c) and Notothenia rossii (d,e,f). Simulated post-larval densities for 1997 (a,d), 1998 (b,e) and $2000(\mathrm{c}, \mathrm{f})$. - spawning sites. Post-larval densities are derived from the locations of the larvae at the end of their planktonic phases, amalgamating all spawning sites and times. Colour bar: number of larvae per coarse grid cell

\section{RESULTS}

Predicted larval dispersal and retention of Champsocephalus gunnari and Notothenia rossii is illustrated in Fig. 4, which shows the density of postlarvae of both species in each of the 3 study years, integrated onto a grid of one-third the resolution of the hydrodynamic model grid, and amalgamating all spawning sites and times. Here, post-larval densities are derived from the locations of the larvae at the end of their planktonic phases. There is high inter-annual variability in the predicted distributions for both species, with general trends for off-shelf transport to the north of South Georgia and to the northwest of Shag Rocks. C. gunnari post-larvae are concentrated to the north and west of South Georgia for 1997, with high- 


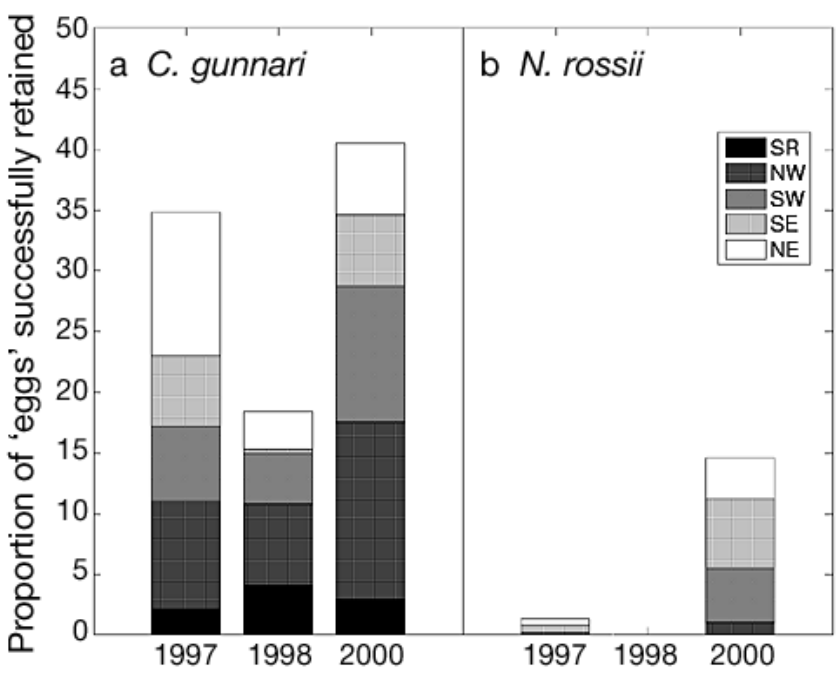

Fig. 5. Champsocephalus gunnari (a) and Notothenia rossii (b). Inter-annual variability in larval retention, with bars subdivided to show retention within specific shelf regions around South Georgia (NW, SW, SE, NE) and Shag Rocks (SR) (see also Fig. 1). A larva was assumed to be retained if it met retention criteria at any time within a $4 \mathrm{wk}$ period at the end of the planktonic phase

est densities to the northwest for 2000. For 1998, the highest densities of $C$. gunnari post-larvae are off the shelf to the north, with a weak area of higher densities on the shelf to the west of South Georgia. Densities of $N$. rossii post-larvae are much lower than those of C. gunnari, with substantial transport off the shelf to the north. Of the 3 study years, significant concentrations on the shelf are only predicted for 2000, with post-larvae widely distributed.

Imposing the species-specific retention criteria described earlier, the overall predicted retention of the early life stages of Notothenia rossii is much lower than that of Champsocephalus gunnari, with a mean retention over the $3 \mathrm{yr}$ of $5.3 \%$, versus the $31.3 \%$ predicted for C. gunnari. However, for both species, the total retention of larvae across the 3 study years reveals significant inter-annual variability (Fig. 5, Table 1), which is especially marked for N. rossii. For both species, 1998 was a poor year, most notably with a prediction of zero retention for $N$. rossii. To illustrate geographical trends in retention, the percentages in Fig. 5 are shaded according to the region in which the larvae were located at the end of their planktonic phase. The NW and SW regions are consistently regions of higher retention for C. gunnari, although there is significant interannual variability, with highest retention within the NE region in 1997 and extremely low retention in
Table 1. Champsocephalus gunnari and Notothenia rossii. Inter-annual variability in larval retention within specific shelf regions around South Georgia (NW, SW, SE, NE) and Shag Rocks (SR) (see also Figs. 1 \& 5). A larva was assumed to be retained if it met retention criteria at any time within a $4 \mathrm{wk}$ period at the end of the planktonic phase

\begin{tabular}{|lrrrrrrrr|}
\hline & \multicolumn{3}{c}{ C. gunnari } & & \multicolumn{3}{c|}{ N. rossii } \\
& 1997 & 1998 & 2000 & & 1997 & 1998 & 2000 \\
\hline SR & 2.1 & 4.0 & 2.9 & & 0.0 & 0.0 & 0.0 \\
NW & 8.9 & 6.8 & 14.6 & & 0.0 & 0.0 & 1.0 \\
SW & 6.1 & 4.2 & 11.2 & & 0.2 & 0.0 & 4.4 \\
SE & 5.8 & 0.4 & 5.8 & 0.7 & 0.0 & 5.8 \\
NE & 11.8 & 3.1 & 6.0 & & 0.5 & 0.0 & 3.4 \\
Total & 34.8 & 18.4 & 40.6 & & 1.3 & 0.0 & 14.6 \\
\hline
\end{tabular}

the SE region in 1998. Retention is strongest in the SE region for $N$. rossii, and weakest within the NW region.

Considering the relative contribution of individual spawning sites to simulated retention (Fig. 6), of the 4 spawning sites on the South Georgia shelf, CG3 and CG4 in the SW are most important to overall Champsocephalus gunnari retention (Fig. 6a; inset box). For Notothenia rossii, spawning site NR1 in the SE has the greatest contribution (Fig. 6b; inset box). Considering retention within specific shelf regions, C. gunnari retention in the NE and SE regions is dominated by contributions from spawning site CG3, whilst the NW and SW regions show the greatest contribution from spawning site CG4. However, the results show high inter-annual variability with, for example, site CG1 contributing significantly to the NW and SW regions in 2000 and to the NE in 1998. Retention of $N$. rossii, although generally very low, is dominated in the NW by contributions from spawning site NR1, whilst the SW region shows the greatest contribution from site NR2. Both spawning sites contribute similarly to retention within the SE and NE regions, with little inter-annual variability. By contrast, there is strong inter-annual variability in the NW and SW, although the analysis is constrained by the poor retention in these regions.

Of particular interest is the failure of Champsocephalus gunnari eggs spawned at Shag Rocks to reach the South Georgia shelf, and vice versa, in all 3 yr (Fig. 6). Particle trajectories (not shown) revealed general trends for transport off the South Georgia shelf to the north and northwest and off the Shag Rocks shelf to the northwest, with no direct transport between the shelf regions. However, in 1998 a small proportion of particles from South Georgia turned westwards to the north of Shag Rocks. Although 

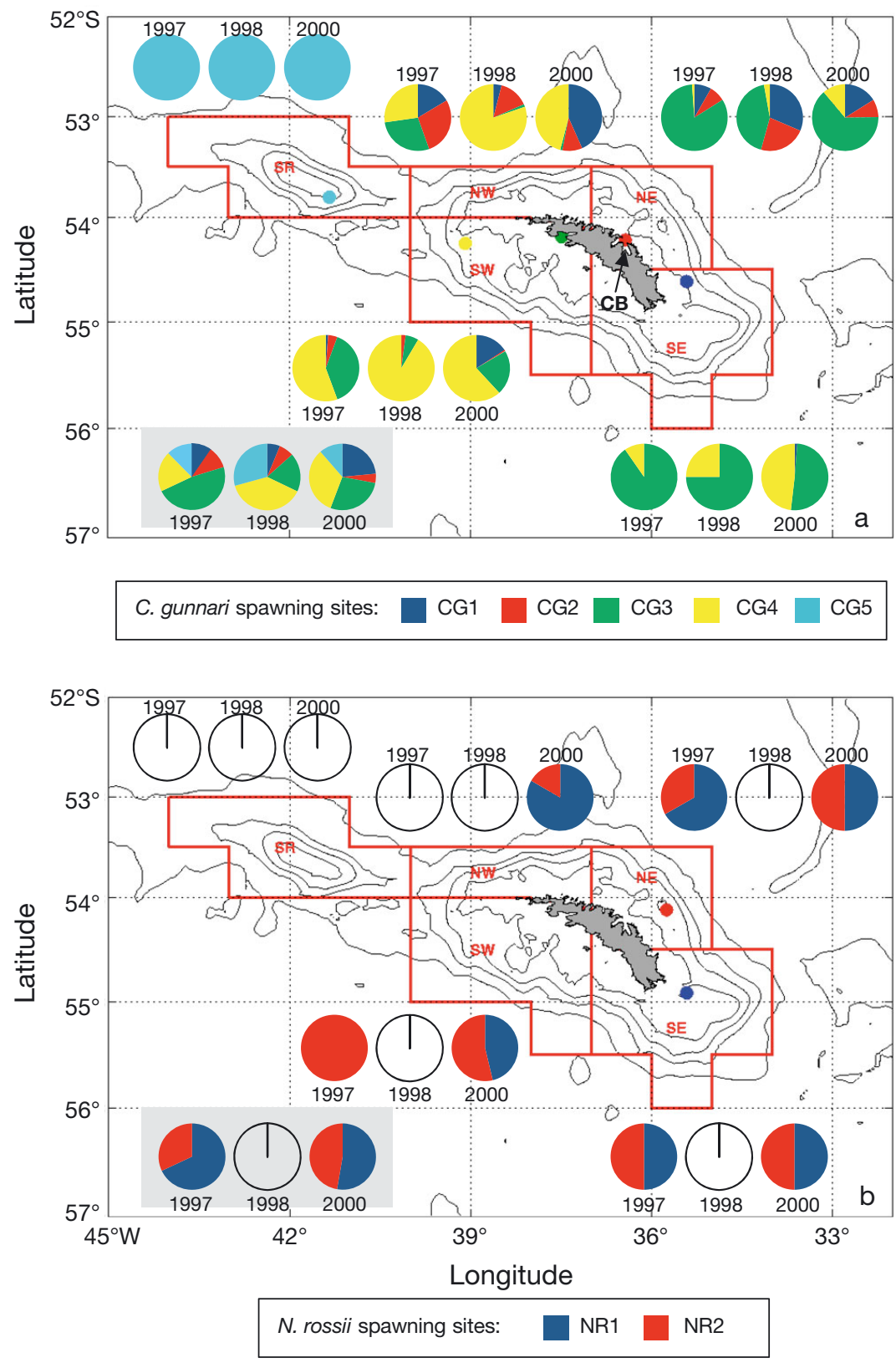

Fig. 6. Champsocephalus gunnari (a) and Notothenia rossii (b). Contribution of individual spawning sites to larval retention within shelf regions (SR, NW, SW, SE and NE; red lines) for yr 1997, 1998 and 2000. A larva was assumed to be retained if it met retention criteria at any time within a 4 wk period at the end of the planktonic phase. Shaded inset boxes: means across all regions for the $3 \mathrm{yr}$ (note, however, the variation in total retention across years illustrated in Fig. 5 and detailed in Table 1). Black arrow in (a): Cumberland Bay $(\mathrm{CB})$

these did not reach Shag Rocks within the assumed 3 mo planktonic phase, 2 particles $(0.1 \%)$ met the retention criteria during the following month, both of which were released at spawning site CG4. Thus, there is the potential for weak, infrequent transport of C. gunnari larvae from South Georgia, specifically the SW shelf, to Shag Rocks.

The inclusion of diel vertical migration behaviour resulted in overall increases in both Champsocephalus gunnari and Notothenia rossii retention, although the effect varied by spawning site and the lack of $N$. rossii retention in 1998 persisted (Fig. 7). The results for $N$. rossii suggest a weak but positive influence of vertical migration behaviour on retention in 1997 and 2000, with an additional 12 larvae retained in each year. This had a larger impact in 1997 when it markedly augmented low retention numbers. Variability occurs between spawning sites, with vertical migration behaviour resulting in a decrease in retention in 1997 for spawning at site NR2. However, this is not repeated in 2000, and is likely to be an artefact of the low levels of retention in 1997. The effect of vertical migration on retention of $C$. gunnari larvae also varies across years and between spawning sites. Of particular interest is spawning site CG2, with relatively low increases in retention predicted for 1997 and 2000 and a decrease predicted for 1998.

The timing of spawning (early, middle, or late) had little effect on levels of retention. Mean Champsocephalus gunnari retention over all years and spawning sites for early, middle and late spawning (vertical migration neglected) was $33.4 \pm$ $22.0,30.7 \pm 24.0$ and $29.8 \pm 25.4 \%$ (mean $\pm \mathrm{SD}$ ). Similarly, Notothenia rossii retention for early, middle and late spawning was $5.3 \pm 6.9,6.5 \pm$ 9.7 and $4.2 \pm 5.9 \%$. However, there was a pronounced reduction in C. gunnari retention for late releases of larvae at site CG2 in all years for the simulations with vertical migration behaviour.

The results of model simulations of Antarctic fish larval retention described above have revealed significant influences of both oceanographic variability and early life-history characteristics and behaviour. 


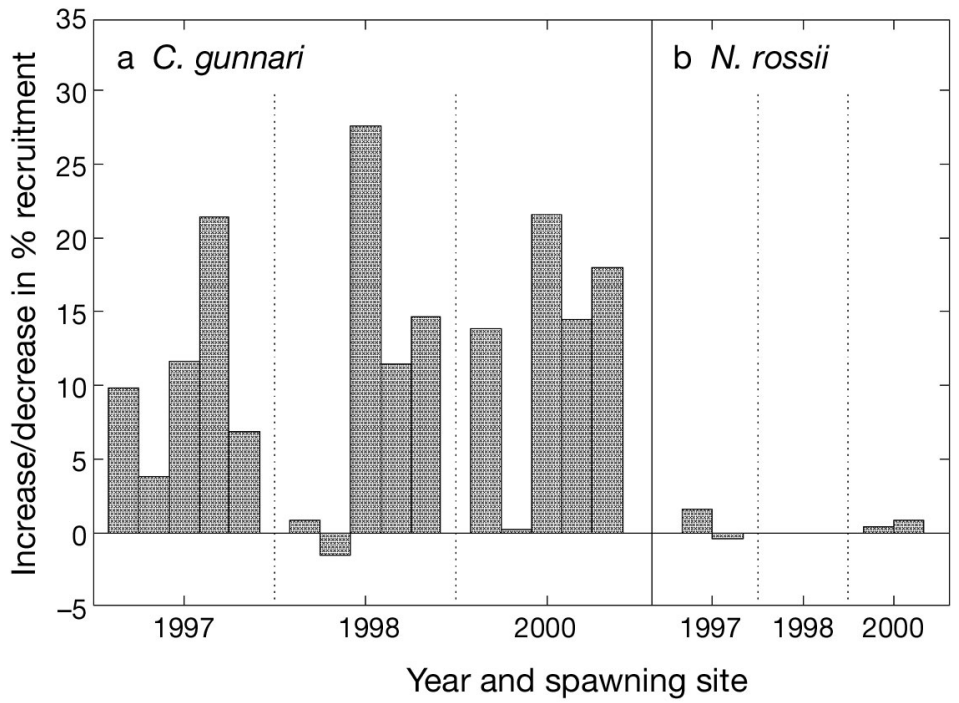

Fig. 7. (a) Champsocephalus gunnari and (b) Notothenia rossii. Effect of vertical migration on larval retention. For each year, the bars for 5 C. gunnari spawning sites are ordered from left to right CG1, CG2, CG3, CG4 and CG5, and for the 2 N. rossii sites, NR1 and NR2

Table 2. Champsocephalus gunnari and Notothenia rossii. Results of ANOVA calculations ( $\mathrm{p}$-values) for larval retention

\begin{tabular}{|lcc|}
\hline Factor & C. gunnari & N. rossii \\
\hline Spawning site & 0.0000 & 0.2675 \\
Year & 0.0000 & 0.0000 \\
Vertical migration & 0.0010 & 0.6607 \\
Spawning time & 0.1698 & 0.0649 \\
\hline
\end{tabular}

To distinguish the relative importance of each of these, analysis of variance (ANOVA) calculations were performed for each species (Table 2). Champsocephalus gunnari retention is significantly influenced (at $>99 \%$ confidence limit) by the location of the spawning site, inter-annual variability in the underlying oceanographic flow fields and vertical migration, but is not significantly influenced by the timing of spawning. By contrast, Notothenia rossii retention is significantly influenced only by interannual variability in flows.

\section{DISCUSSION}

\section{Physical influences}

Model-predicted currents on and around the South Georgia shelf show a high degree of spatial variability, as a result of which the predicted pathways for eggs and larvae released at discrete sites can be markedly different. Although predicted flows also exhibit significant temporal variability, general trends in trajectories for each spawning site can be identified. Champsocephalus gunnari larvae spawned at sites CG1 and CG2 tend to be transported westwards along the northern shelf, with a significant proportion carried off the shelf to the north (mean percentages of larvae failing to be retained of $76.6 \%$ for CG1 and $88.5 \%$ for CG2) and with retained larvae concentrated in the northwest region (Fig. 6). By contrast, larvae spawned at site CG3 are transported in an anticlockwise direction around South Georgia, with those larvae not retained leaving the shelf region to the north. The longer transit route for these larvae results in significantly higher retention rates (mean retention of $52.1 \%$ ), with retention concentrated in the southeast and northeast regions (Fig. 6). The majority of larvae spawned at site CG4 are transported northwards to the region west of South Georgia, where flows are generally weaker and more variable with a persistent gyre feature. Those larvae transported nearer the coast from CG4 are entrained in the anticlockwise near-coast current and follow a similar trajectory to larvae spawned at CG3. Both these routes result in significant retention (mean retention of $45.4 \%$ ), with the highest concentrations of retained larvae in the northwest and southwest regions (Fig. 6). Egg and larval trajectories for Notothenia rossii show little difference between the 2 spawning sites, with westward transport along the northern shelf and significant off-shelf transport to the north and northwest. Although not statistically significant (Table 2), retention for site NR1 is slightly higher than that for site NR2, as the latter lies nearer the shelf edge and dominant off-shelf transport routes. Significantly fewer larvae are retained for this species than for $C$. gunnari (overall mean retention of $5.3 \%$ ) due to the long planktonic phase in relation to the transit time along the northern South Georgia shelf. However, such life-history variation also allows a few larvae to circumnavigate the island successfully; on reaching the region to the west of South Georgia, a minority of larvae become entrained in the periodic shelf-wide anticlockwise flow and continue back towards their spawning ground. Hence, the highest concentration of retained $N$. rossii larvae is predicted for the $\mathrm{SE}$ region (Fig. 5). 
The general trends in egg and larval trajectories discussed above highlight the significant influence of the location of spawning site on Champsocephalus gunnari retention, with little effect seen for the retention of Notothenia rossii larvae. However, these broad patterns are also perturbed by temporal variability in the currents, with a significant influence of inter-annual variability in the underlying oceanographic flows on retention. The more westerly location of the SACCF in 1998 and stronger anticlockwise coastal current led to increased off-shelf transport for larvae released at sites CG2, CG3 and CG4, resulting in lower retention. Retention from spawning at site CG3 was predicted to be lower in 2000 than in 1997 due to the enhanced anticlockwise coastal current, which reduced the transit time for $C$. gunnari larvae to the northern shelf, thus increasing the potential for offshelf transport. By contrast, retention from spawning at site CG4 was poorer in 1997 as the dominant off-shelf transport route was furthest west in this year. The planktonic phases of $C$. gunnari larvae spawned at site CG1, and of $N$. rossii eggs, predominantly occur during austral winter. The mean residual flows for austral winter in 2000 showed an anticlockwise shelf current circumnavigating the island. Such conditions were also weakly evident in 1997 but were not predicted in 1998. Thus, a proportion of eggs/larvae released at these sites in 2000 were transported anticlockwise around the NW tip of South Georgia and onto the southern shelf, with consequent higher retention that year. To a lesser degree the effect was also seen for $N$. rossii larvae in 1997, but did not occur in 1998, when no larvae were successfully retained. By contrast, there was little inter-annual variability in retention for spawning at Shag Rocks (CG5) due to weak predicted variability in the flows.

Whilst temporal variability in the oceanographic flows at South Georgia resulted in significant interannual variability in retention, the timing of spawning within the 2 mo spawning period did not have a significant effect. These findings suggest that largescale, long-period variability in the flows, for example due to variability in the path of the SACCF, dominates the oceanographic influence.

\section{Behavioural influences}

Vertical migration is a recognised mechanism for inducing directed horizontal transport and increased recruitment in the marine environment.
Periodic vertical migration in a steady, sheared current can result in unidirectional transport of larvae. Such an effect has been postulated in the estuarine environment where the long-term, sub-tidal flow usually exhibits seaward flow at the surface and landward flow near the bottom (Fortier \& Leggett 1983). In shelf environments, vertical migration may couple with vertically stratified flows to retain larvae nearshore (Cowen et al. 2000), and interaction with both semi-diurnal and diurnal tidal currents may induce a net horizontal transport (Hill 1991a,b).

On the South Georgia and Shag Rocks shelves, tides are weak; the mean speed of the dominant diurnal tidal constituent $\left(K_{1}\right)$ is $\sim 0.05 \mathrm{~m} \mathrm{~s}^{-1}$, with high spatial variability. Thus, interaction of vertical migration with tidal currents is unlikely to be a significant influence on horizontal larval movement. Vertical stratification on the South Georgia shelf does not generally develop until December, towards the end of the Champsocephalus gunnari and Notothenia rossii planktonic phases; thus, it is also unlikely to be a significant influence. However, vertical migration of $C$. gunnari larvae was predicted to increase overall retention. Considering the vertical distribution of the larvae, a greater proportion of their time was spent in the near-bed layer in the simulations with vertical migration than in those with a random vertical distribution. Due to vertical shear in current speed, they therefore experienced weaker currents (Fig. 3). In addition, wind-induced Ekman transport on the northern shelf generates an off-shelf component to the flows in the upper layers of the water column, whilst the mean flows at a depth of $100 \mathrm{~m}$ are directed along the shelf. Increased time at depth therefore reduces the likelihood of off-shelf transport. However, contradictory to this general picture, vertical migration of $C$. gunnari larvae released at site CG2 had a variable influence on retention, with lower retention predicted overall for 1998 and for larvae released in the latter third of the hatching period in 1997. This site is situated at the mouth of Cumberland Bay (Fig. 6), where there is significant freshwater discharge. The freshwater fluxes, which start to increase during September and peak in February, generate an off-shelf, nearsurface flow (Fig. 3b). The simulated vertical migration pattern maintains the vertical position of the larvae within this near-surface layer during the day (Fig. 3), resulting in increased off-shelf transport. Whilst this was balanced by reduced off-shelf transport during the deeper phase of the diel verti- 
cal migration in 1997 and 2000, it led to greater off-shelf transport in 1998 than that predicted for a random vertical distribution. The reduction in $C$. gunnari retention due to vertical migration was particularly notable for larvae released later in the hatching period at site CG2, when both day length and freshwater discharges (and thus the strength of the off-shelf flow) are increased. By contrast, vertical migratory behaviour had no significant effect on the retention of $N$. rossii larvae, due predominantly to the long egg phase of this species (4 mo), during which a high proportion of eggs was transported off the shelf. Subsequent larval vertical migration did not result in movement of these individuals back to suitable shelf retention areas.

\section{Connectivity between South Georgia and Shag Rocks}

No exchange of Champsocephalus gunnari larvae between the South Georgia and Shag Rocks shelves was predicted by the model simulations, either with or without vertical migratory behaviour. Very weak transport from spawning site CG4 to Shag Rocks was predicted in 1998, but this was only achieved if the planktonic phase was increased by a month. Such predictions pose significant biological constraints on dispersal as the lecithotrophic stage of this species at South Georgia lasts $\sim 2$ to 3 wk (M. Belchier unpubl. data). A larva would require exogenous food resources during the period of transport between regions, and whilst some prey would be transported off the shelf with the larvae, once these resources were depleted, the opportunity for replenishment in the open ocean would be limited. Survival rates for these larvae are therefore likely to be lower than for those retained on the shelf. The lack of larval exchange between South Georgia and Shag Rocks is predominantly due to a strong and persistent full-depth northward flow between the shelves that acts as a barrier to passive dispersal (Fig. 2).

The lack of predicted larval exchange between South Georgia and Shag Rocks provides the underlying physical mechanism for observations of separate Champsocephalus gunnari stocks at the 2 sites (Carvalho \& Lloyd-Evans 1990, Sosinski \& Janusz 2000, North 2005). However, genetic analyses have suggested a higher degree of genetic similarity between adult C. gunnari at South Georgia and Shag Rocks than with populations elsewhere in the Scotia Sea
(Kuhn \& Gaffney 2006). Parallel to the modelling study described here, genetic analyses of adult C. gunnari sampled at 3 locations (CG1, CG4 and CG5; Fig. 6) were performed, and no significant differentiation was found between populations at South Georgia and Shag Rocks (J. Rock unpubl. data). In addition, complementary to the model predictions of persistent larval transport from CG4 to the eastern South Georgia shelf, a very high connectivity was found between CG4 and CG1. These results suggest that larval transport may not be the dominant process for gene flow between South Georgia and Shag Rocks. Rather, it seems likely that genetic similarities are largely due to adult migrations, for example from Shag Rocks to the major feeding grounds on the northern South Georgia shelf. Such an uncoupling of realised larval and adult dispersal is likely to be a common feature of marine taxa (e.g. Hauser \& Carvalho 2008), but also highlights the limitations of using larval dispersal alone as a predictor of population connectivity.

\section{Broader implications}

The Notothenia rossii population at South Georgia collapsed in the 1970s due to over-fishing, and it has failed to recover (Kock et al. 2004). This situation may have arisen in part from poor retention of the egg and larval phases due to the long planktonic period and offshore spawning sites, with a high proportion (mean of $94.7 \%$ ) predicted to be transported off the South Georgia shelf to the north. Genetic analyses of $N$. rossii stocks in the Scotia Sea (J. Rock unpubl. data) suggest a high degree of connectivity between South Georgia and islands in the southern Scotia arc. However, whilst a small percentage of eggs and larvae from these southern spawning grounds are predicted to reach a geographical region encompassing South Georgia (mean of $~ 3 \%$; E. F. Young unpubl. data), very few reach suitable recruitment areas on the South Georgia shelf. Such influx would be sufficient to promote genetic homogeneity, though it does not appear to have a significant impact on the size of the South Georgia population. An additional consideration in relation to mortality factors is the local fur seal population, which has increased from an estimated population of 1.5 million in 1991 to $\sim 4$ million at present (Staniland et al. 2010). Fur seals are a known predator of small fish in the region; hence, increased predation on juvenile $N$. rossii may further constrain the recovery of $N$. rossii stocks. 
Management of South Georgia and Shag Rocks Champsocephalus gunnari populations as separate fisheries units has been the subject of much debate (North 1996, Frolkina 2001, Kock 2005, North 2005). The lack of larval connectivity predicted in the present study implies that the spawning stocks should be treated separately for fisheries management purposes. On the South Georgia shelf, spawning sites in the SW region are predicted to have a dominant influence on $C$. gunnari retention, thereby suggesting that the impacts of fishing activity in this region during the spawning period should be considered in sustainable management plans. However, site CG2 (Cumberland Bay; Fig. 6) is not adequately resolved in the hydrodynamic model, and C. gunnari eggs spawned here may in practice have a greater chance of retention. Indeed, field studies of larval C. gunnari have found concentrations within Cumberland Bay to be an order of magnitude higher than in adjacent coastal waters, suggesting significant local retention within the bay (Everson et al. 2001). A high level of interannual variability in retention was predicted at South Georgia, suggesting that this could be a key factor in the observed variability in C. gunnari population size. However, such variability will combine with other influences on stock size, which may mask any observable effect.

Our study has demonstrated how physical and behavioural variability influence the transport and retention of the planktonic phases of Champsocephalus gunnari and Notothenia rossii around South Georgia. Modelling studies inevitably have their limitations, which, in this case, include insufficient resolution of coastal bays in the underlying hydrodynamic model and the neglect of biological features such as variability in mortality and spawning stock size. However, the results provide insights into the ecology of fish populations in the region and demonstrate the complex interactions between behaviour, geographic location and temporal environmental variability, facets influencing sustainable practices for fishery resources.

Acknowledgements. This work was supported by Natural Environment Research Council (UK) Grant AFI6/16. We thank 2 anonymous referees for their helpful comments.

\section{LITERATURE CITED}

Agnew D (2004) Fishing South. The history and management of South Georgia fisheries. Penna Press, St. Albans
Bartsch J, Coombs SH (2004) An individual-based model of the early life history of mackerel (Scomber scombrus) in the eastern North Atlantic, simulating transport, growth and mortality. Fish Oceanogr 13:365-379

> Brandon MA, Murphy EJ, Whitehouse MJ, Trathan PN, Murray AWA, Bone DG, Priddle J (1999) The shelf break front to the east of the sub-Antarctic island of South Georgia. Cont Shelf Res 19:799-819

> Brandon MA, Murphy EJ, Trathan PN, Bone DG (2000) Physical oceanographic conditions to the northwest of the sub-Antarctic Island of South Georgia. J Geophys Res C 105:23983-23996

Carvalho GR, Lloyd-Evans DP (1990) Pilot study on electrophoretic variation and stock structure in the mackerel icefish, Champsocephalus gunnari, from South Georgia waters. Research Report for the Government of South Georgia and South Sandwich Islands, University of Wales, Bangor

> Cowen RK, Sponaugle S (2009) Larval dispersal and marine population connectivity. Annu Rev Mar Sci 1: 443-466

Cowen RK, Lwiza KMM, Sponaugle S, Paris CB, Olson DB (2000) Connectivity of marine populations: Open or closed? Science 287:857-859

Daewel U, Peck MA, Kuhn W, St John MA, Alekseeva I, Schrum C (2008) Coupling ecosystem and individualbased models to simulate the influence of environmental variability on potential growth and survival of larval sprat (Sprattus sprattus L.) in the North Sea. Fish Oceanogr 17:333-351

Dickey-Collas M, Armstrong MJ, Officer RA, Wright PJ, Brown J, Dunn MR, Young EF (2003) Growth and expansion of haddock (Melanogrammus aeglefinus L.) stocks to the west of the British Isles in the 1990's. ICES Mar Sci Symp 219:271-282

Duhamel G (1995) New data on spawning, hatching and growth of Champsocephalus gunnari on the shelf of the Kerguelen Islands. CCAMLR Sci 2:21-34

Dyke P (2001) Coastal and shelf sea modelling. Kluwer Academic, Boston, MA

Egbert GD, Erofeeva SY (2002) Efficient inverse modeling of barotropic ocean tides. J Atmos Ocean Technol 19: 183-204

Everson I, North AW, Paul A, Cooper R, McWilliam NC, Kock KH (2001) Spawning locations of mackerel icefish at South Georgia. CCAMLR Sci 8:107-118

> Fortier L, Leggett WC (1983) Vertical migrations and transport of larval fish in a partially mixed estuary. Can J Fish Aquat Sci 40:1543-1555

Forward RB (1988) Diel vertical migration - Zooplankton photobiology and behavior. Oceanogr Mar Biol Annu Rev 26:361-393

> Fox CJ, Mccloghrie P, Young EF, Nash RDM (2006) The importance of individual behaviour for successful settlement of juvenile plaice (Pleuronectes platessa L.): a modelling and field study in the eastern Irish Sea. Fish Oceanogr 15:301-313

Frolkina GA (2001) Age-length composition of mackerel icefish (Champsocephalus gunnari, Perciformes, Notothenioidei, Channichthyidae) from different parts of the South Georgia shelf. CCAMLR Sci 8:133-146 
Frolkina ZA (2002) Distribution of mackerel icefish (Champsocephalus gunnari) (Channichthyidae) around South Georgia at various stages of its life cycle. CCAMLR Sci 9: 49-69

Gon OE, Heemstra PCE (1990) Fishes of the Southern Ocean. J.L.B. Smith Institute of Ichthyology, Grahamstown

Hauser L, Carvalho GR (2008) Paradigm shifts in marine fisheries genetics: ugly hypotheses slain by beautiful facts. Fish Fish 9:333-362

Hill AE (1991a) A mechanism for horizontal zooplankton transport by vertical migration in tidal currents. Mar Biol 111:485-492

Hill AE (1991b) Vertical migration in tidal currents. Mar Ecol Prog Ser 75:39-54

Holt JT, James ID (2001) An $s$ coordinate density evolving model of the northwest European continental shelf. 1. Model description and density structure. J Phys Oceanogr 106:14015-14034

> Kock KH (2005) Antarctic icefishes (Channichthyidae): a unique family of fishes. A review, Part II. Polar Biol 28: 897-909

Kock KH, Everson I (2003) Shedding new light on the life cycle of mackerel icefish in the Southern Ocean. J Fish Biol 63:1-21

Kock KH, Kellermann A (1991) Reproduction in Antarctic notothenioid fish. Antarct Sci 3:125-150

Kock KH, Belchier M, Jones CD (2004) Is the attempt to estimate the biomass of antarctic fish from a multi-species survey appropriate for all targeted species? Notothenia rossii in the Atlantic Ocean sector - Revisited. CCAMLR Sci 11:141-153

Kock KH, Reid K, Croxall J, Nicol S (2007) Fisheries in the Southern Ocean: an ecosystem approach. Philos Trans R Soc Lond B 362:2333-2349

Kuhn KL, Gaffney PM (2006) Preliminary assessment of population structure in the mackerel icefish (Champsocephalus gunnari). Polar Biol 29:927-935

Lowe WH, Allendorf FW (2010) What can genetics tell us about population connectivity? Mol Ecol 19:3038-3051

Meredith MP, Watkins JL, Murphy EJ, Cunningham NJ and others (2003a) An anticyclonic circulation above the Northwest Georgia Rise, Southern Ocean. Geophys Res Lett 30 (20), 2061, doi:10.1029/2003GLO18039

Meredith MP, Watkins JL, Murphy EJ, Ward P, Bone DG, Thorpe SE, Grant SA, Ladkin RS (2003b) Southern ACC front to the northeast of South Georgia: pathways, characteristics, and fluxes. J Geophys Res 108 (C5), 3162, doi: 10.1029/2001JC001227

> Meredith MP, Brandon MA, Murphy EJ, Trathan PN and others (2005) Variability in hydrographic conditions to the east and northwest of South Georgia, 1996-2001. J Mar Syst 53:143-167

> Meredith MP, Murphy EJ, Hawker EJ, King JC, Wallace MI (2008) On the interannual variability of ocean temperatures around South Georgia, Southern Ocean: forcing by El Nino/Southern Oscillation and the Southern Annular Mode. Deep-Sea Res II 55:2007-2022

Moore JK, Abbott MR, Richman JG (1997) Variability in the location of the Antarctic Polar Front $\left(90^{\circ}-20^{\circ} \mathrm{W}\right)$ from satellite sea surface temperature data. J Geophys Res
102:27825-27833

- Myers RA, Worm B (2003) Rapid worldwide depletion of predatory fish communities. Nature 423:280-283

North AW (1996) Population differentiation by size for 0-age-class Champsocephalus gunnari at Shag Rocks and South Georgia, CCAMLR subarea 48.3. Antarct Sci 8:31-35

North AW (2005) Mackerel icefish size and age differences and long-term change at South Georgia and Shag Rocks. J Fish Biol 67:1666-1685

North AW, Murray AWA (1992) Abundance and diurnal vertical-distribution of fish larvae in early spring and summer in a fjord at South Georgia. Antarct Sci 4:405-412

Orsi AH, Whitworth T, Nowlin WD (1995) On the meridional extent and fronts of the Antarctic Circumpolar Current. Deep-Sea Res I 42:641-673

Proctor R, James ID (1996) A fine-resolution 3D model of the southern North Sea. J Mar Syst 8:285-295

Smith WF, Sandwell DT (1997) Global seafloor topography from satellite altimetry and ship depth soundings. Science 277:1956-1962

> Song YH, Haidvogel D (1994) A semiimplicit ocean circulation model using a generalized topography-following coordinate system. J Comput Phys 115:228-244

Sosinski J, Janusz J (2000) Infection variability of the parasitic copepod Eubrachiella antarctica (Quidor, 1906) on fishes in the Atlantic sector of the Antarctic. Bull Sea Fish Inst 2:25-42

Sponaugle S, Cowen RK, Shanks A, Morgan SG and others (2002) Predicting self-recruitment in marine populations: biophysical correlates and mechanisms. Bull Mar Sci 70: 341-375

Staniland IJ, Gales N, Warren NL, Robinson SL, Goldsworthy SD, Casper RM (2010) Geographical variation in the behaviour of a central place forager: Antarctic fur seals foraging in contrasting environments. Mar Biol 157: 2383-2396

Thorpe SE (2001) Variability of the southern Antarctic Circumpolar Current in the Scotia Sea and its implications for transport to South Georgia. PhD thesis, University of East Anglia, Norwich

> Thorpe SE, Heywood KJ, Brandon MA, Stevens DP (2002) Variability of the southern Antarctic Circumpolar Current front north of South Georgia. J Mar Syst 37:87-105

Trippel EA, Chambers RC (1997) The early life history of fishes and its role in recruitment processes. In: Chambers RC, Trippel EA (eds) Early life history and recruitment in fish populations. Chapman \& Hall, London

> Uppala SM, Kallberg PW, Simmons AJ, Andrae U and others (2005) The ERA-40 re-analysis. Q J R Meteorol Soc 131: 2961-3012

> Vaughan DG (2006) Recent trends in melting conditions on the Antarctic Peninsula and their implications for icesheet mass balance and sea level. Arct Antarct Alp Res 38:147-152

> Ward P, Whitehouse M, Shreeve R, Thorpe S and others (2007) Plankton community structure south and west of South Georgia (Southern Ocean): links with production and physical forcing. Deep-Sea Res I 54:1871-1889

Webb DJ, de Cuevas BA, Coward AC (1998) The first main run of the OCCAM global ocean model. In: Internal 
document. Southampton Oceanography Centre, Southhampton, no. 34

Werner FE, Quinlan JA, Lough RG, Lynch DR (2001) Spatially-explicit individual based modeling of marine populations: a review of the advances in the 1990s. Sarsia 86: 411-421

Whitehouse MJ, Meredith MP, Rothery P, Atkinson A, Ward P, Korb RE (2008) Rapid warming of the ocean around South Georgia, Southern Ocean, during the 20th cen-

Editorial responsibility: Nicholas Tolimieri, Seattle, Washington, USA tury: forcings, characteristics and implications for lower trophic levels. Deep-Sea Res I 55:1218-1228

Young EF (1996) Environmental influences on bivalve recruitment in The Wash. PhD thesis, University of East Anglia, Norwich

Young EF, Meredith MP, Murphy EJ, Carvalho GR (2011) High-resolution modelling of the shelf and open ocean adjacent to South Georgia, Southern Ocean. Deep-Sea Res II 58:1540-1552

Submitted: December 9, 2011; Accepted: June 26, 2012 Proofs received from author(s): September 18, 2012 